\title{
KONSEP DASAR PERENCANAAN KEPERAWATAN DALAM MELAKUKAN ASUHAN KEPERAWATAN
}

\section{Rahel Juliana Benedikta Berutu}

\section{Email : beruturahel1507@gmail.com}

\section{Latar Belakang}

Asuhan keperawatan adalah tindakan perawat dalam memberikan pelayanan kesehatan secara kolaboratif yaitu bekerjasama dengan tim medis lainnya. Hal ini dilakukan untuk mewujudkan asuhan keperawatan yang Holistic dan menyeluruh serta menjadi tanggung jawab perawat dalam tatanan pelayanan. Asuhan keperawatan terdiri dari beberapa tahap. Yang pertama di lakukan yaitu pengkajian yang berguna untuk mengumpulkan data baik secara subjektif maupun objektif. Setelah di lakukan pengkajian, tahap selanjutnya adalah menentukan diagnosa keperawatan. Perencanaan keperawatan merupakan tahap pada proses keperawatan yang dilakukan setelah penegakan Diagnosa Keperawatan. Perencanaan keperawatan adalah suatu rangkaian kegiatan penentuan langkah-langkah pemecahan masalah dan prioritasnya, perumusan tujuan, rencana tindakan dan penilaian asuhan keperawatan pada pasien atau klien berdasarkan analisis data dan diagnosa keperawatan. Tujuan dari perencanaan keperawatan adalah untuk mecapai kesejahteraan kesehatan klien dan kemandirian klien menjaga kesehatannya.. Perencanakan keperawatan dapat menghasilkan implementasi keperawatan yang tepat karna sudah mempunyai pedoman rencana tindakan yang ingin diimplementasikan kepada klien.Dalam membuat rencana keperawatan, ada beberapa hal yang perlu untuk diperhatikan yaitu menentukan Prioritas masalah,menentukan tujuan dan kriteria Hasil dan menentukan rencana tindakan keperawatan. Perencanaan keperawatan sangat penting untuk mencapai kesehatan klien dan kesejahteraan klien. Manfaat perencaan keperawatan dalam asuhan keperawatan yaitu sebagai penghubung kebutuhan klien atau pasien, tahap untuk menjelaskan intervensi 
keperawatan sebalum melakukan implementasi, meningkatkan praktik asuhan keperawatan, serta sebagai dasar pendekatan yang sistematis dalam asuhan keperawatan. Metode perencanaan asuhan keperawatan sangat di butuhkan dalam memberikan pelayanan kesehatan secara holistic. Sehingga perencanaan keperawatan di pahami sebagai pendekatan yang sistematik dalam mencegah dan mengatasi masalah kesehatan baik secara aktual maupun potensial serta mendukung kesejahteraan perawatan dalam memberikan pelayanab human caring.

Kata kunci : konsep dasar, perencanaan keperawatan, asuhan keperawatan.

\section{Metode}

Metode penulisan yang digunakan dalam penulisan laporan ini adalah literature review. Literature review yang dilakukan berupa telaah pustaka artikel penelitian. Artikel dipublikasikan secara elektronik dan diunduh melalui Google Scholar,science direct, scopus, ebook, dan dari beberapa buku keperawatan.. Kata Kunci yang digunakan yaitu Konsep dasar, Perencanaan keperawatan, dan Asuhan keperawatan. Kriteria inklusi artikel adalah diterbitkan dari tahun 2012 hingga 2020, dan fulltext. Prosedur pengumpulan data yang digunakan adalah menentukan keyword untuk pencarian literatur yang relevan dengan topik kajian dan melakukan penelusuran mengenai topik relevan.

\section{Hasil}

Jurnal dengan judul Konsep Perencanaan Keperawatan bertujuan untuk mencapai kesejahteraan klien dan kemandirian klien menjaga kesehatannya. Metode yng digunakan yaitu metode pengumpulan data. Hasilnya yaitu perencanaan keperawatan dapat menghasilkan implementasi keperawatan yang tepat karena sudah memiliki pedoman rencana tindakan yang ingin diimplementasikan kepada klien atau pasien.

Berdasarkan Jurnal Nursing Studies, Volume 1, Nomor 1 Tahun 2012 , tingkat pencapaian kesempurnaan pemberian asuhan keperawatan sangat tergantung dari kemauan, kemampuan, pengetahuan, dan keterampilan yang baik dari perawat. Selain itu juga harus ditunjang dengan tersedianya fasilitas secara memadai, kondisi kuantitas yang sesuasi, penempatan yang tepat serta persiapan perawat yang baik. Pengetahuan dan keterampilan 
yang baik tidak lepas dari kompetensi yang didapat selama proses pembelajaran, baik dalam bentuk teori maupun praktik. Kompetensi ini menekankan bahwa asuhan keperawatan harus dilakukan secara komprehnsif, baik tindakan preventif.

Jurnal dengan judul Tahapan Perencanaan Asuhan Keperawatan bertujuan untuk mengetahui tahapan perencanaan asuhan keperawatan yang akan diberikan kepada klien agar pemenuhan pelayanan dapat berjalan dengan baik. Hasil nya adalah perencanaan asuhan keperawatan dikategorikan baik karena perencanaan keperawatan sangat penting pada asuhan keperawatan sebelum melakukan tindakan.

Judul dengan jurnal Pengetahuan Dan Sikap Perawat Terhadap Perencanaan Asuhan Keperawatan. Tujuannya adalah untuk mendoorng perawat dan mahasiswa agar melakukan perencanaan keperawatan yang tepat sesuai dengan standar konsep dasar. Hasil dari data yang telah dikumpulkan dari berbagai sumber, banyakperawat yang telah melakukan perencanaan keperawatan dalam memberikan asuhan keperawatan yang tepat pada pasien.

Jurnal dengan judul Pengetahuan Dan Sikap Perawat Terhadap Perencanaan Asuhan Keperawatan, bertujuan untuk mengetahui tentang perencanaan, asuhan keperawatan, dan mengapa pentingnya perencanaan dalam asuhan keperawatan. Hasil dari tahap perencanaan adalah untuk mengidentifikasi seluruh kebutuhan yang diperlukan klien. Kebutuhan ini menggambarkan masalah yang terjadi pada klienbaik actual maupun risiko

Jurnal dengan judul Tahapan Perencanaan dalam Proses Asuhan Keperawatan bertujuan untuk mengetahui tahapan atau langkah-langkah dari perencanaan dalam proses asuhankeperawatan. Perencanaan Keperawatan merupakan suatu proses penyusunan berbagai intervensi keperawatan yang dibutuhkan untuk mencegah, menurunkan, atau mengurangi masalah-masalah klien. Perencanaan ini merupakan langkah ketiga dalam membuat suatu proses keperawatan. Langkah-langkah perencanaan yaitu sebagai berikut: Penentuan prioritas diagnosis, Penentuan tujuan dan hasil yang diharapkan. Untuk memudahkan dalam menentukan rencana tindakan.

Judul dengan jurnal Pentingnya Perencanaan Asuhan Keperawatan,bertujuan untuk memberi informasi kepada pembaca khususnya para perawat atau yang sedang mengikuti pendidikan keperawatan mengenai pentingnya perancanaan asuhan keperawatan sehingga asuhan keperawatan dapat dengan mudah dan cepat serta tepat untuk dilaksanakan. Hasil yang diperoleh menunjukkan bahwa perencaaan dalam asuhan keperawatan sangat perlu 
untuk dilakukan agar mempermudah perawat dalam melakukan asuhan keperawatan sesuai dengan kebutuhan yang harus dipenuhi terhadap pasien. Sehingga perlu bagi perawat untuk mempersiapkan segara perencanaan asuhan keperawatan dengan benardan tepat sehingga asuhan keperawatan dapat diberikan sesuai dengan kebutuhan pasien

\section{Pembahasan}

Berdasarkan hasil literature saya, bahwa perawat yang professional dalam memberikan asuhan keperawatan pasti akan mempersiapkan perencanaan keperawatan yang akan diimplementasikan sesuai dengan konsep dasar keperawatan .

Perencanaan adalah suatu proses keperawatan yang meliputi pembuatan keputusan dan pemecahan masalah. Dalam perencanaan keperawatan, perawat menetapkan sesuai dengan hasil pengumpulan data pada tahap pengkajian serta rumusan diagnosa keperawatan yang merupakan tujuan awal dari asuhan keperawatan. Langkah-langkah dalam membuat perencanaan keperawatan adalah menetapkan prioritas masalah, menetapkan tujuan atau hasil yang di harapkan serta menentukan intervensi keperawatan yang tepat dalam rencana asuhan keperawatan. Rencana tindakan adalah suatu hal yang sangat penting dalam intervensi untuk membantu klien mencapai kesejahteraan dan kesehatan. Di butuhkan kesadaran perawat dalam menyusun perencanaan agar kinerja perawat semakin meningkat. Pengetahuan dan motivasi perawat juga berpengaruh, salah satu literature saya menunjukkan bahwa perawat yang memiliki pengetahuan yang tinggi mengenai proses keperawtan termasuk intervensi keperawatan akan dapat memeberikan pelayanan yang semakin baik kepada pasien. Semakin tinggi pengetahuan perawat maka akan semakin baik pula perawat menerapkan perencanaan yang telah dipersiapkan. Ini menunjukkan pengetahuan yang dimiliki perawat menentukan ketepatan perawat dalam memberikan pelayanan.

Rencana asuhan keperawatan adalah petunjuk tertulis yang menggambarkan secara tepat mengenai rencana tindakan yang dilakukan terhadap klien sesuai dengan kebutuhannya berdasarkan diagnosis keperawatan. Rencana asuhan keperawatan ini bertujuan sebagai alat komunikasi antara sesama anggota perawatan dan antar tim kesehatan lainnya, untuk meningkatkan kesinambungan asuhan keperawatan terhadap klien, serta membantu dalam mendokumentasikan proses dan kriteria hasil asuhan keperawatan yang akan dicapai.

Langkah langkah yang perlu di lakukan dalam konsep perencanaan keperawatan untuk memberi asuhan keperawata yang di inginkan yaitu dengan menetapkan urutan prioritas diagnosis keperawatan, kemudian menentukan tujuan asuhan keperawatan, selanjutnya menentukan rencana intervensi keperawatan, dan terakhir menuliskan rencana 
asuhan keperawatan. Dalam merumuskan tujuan, perawat harus merumuskan berdasarkan masalah atau diagnosis keperawatan, rumusan merupakan hasil akhir yang ingin di capai, harus bersifat objektif, tujuan perawat harus sejalan dengan tujuan klien, bisa mencakup tujuan masa pendek maupun panjang, mencakup kriteria keberhasilan dan dapat menjadi pedoman dari tindakan keperawatan dalam asuhan keperawatan.

Suatu pernyataan tujuan pertama-tama diperlukan agar perawat tahu secara khusus apa yang perawat harapkan untuk dicapai bersama-sama dengan klien. Tanpa suatu pernyataan tujuan yang jelas, perawat tidak mengetahui apakah akhir yang diinginkan telah tercapai. Suatu pernyataan tujuan yang jelas, akan menunjukkan hasil dari tindakan keperawatan dan batas waktu yang dibutuhkan.

Terdapat dua kategori tujuan, yaitu janga pende dan jangka panjang. Tujuan jangka panjang adalah hasil yang dalam pencapaiannya memerlukan waktu lebih lama. Tujuan jangka pendek tepat digunakan untuk keadaan emergensi dimana kondisi klien tidak stabil.

Kriteria Rumusan Tujuan Keperawatan yaitu berfokus kepada klien. Pernyataan tujuan harus merupakan perilaku klien yang menunjukkan berkurangnya masalah klien. Masalah tersebut telah diidentifikasikan dalam diagnosis keperawatan, jelas dan singkat, dapat diukur dan diobservasi, waktu relatif dibatasi (jangka pendek, menengah dan panjang), realistik untuk kemampuan/kondisi klien dalam waktu seperti yang ditetapkan, realistik untuk tingkat pengalaman dan ketrampilan perawat, ditentukan bersama oleh perawat dan klien, dan tujuan harus sejalan dan menyokong terapi lain

Perumusan Kriteria Keberhasilan yaang di maksud yaitu merupakan model atau standar yang digunakan untu membuat keputusan, dinyatakan sebagai hasil, misalnya merupakan perubahan status kesehatan, menentukan apakah tujuan dapat dicapai, menentukan kriteria keberhasilan yang ditentukan, yang mencakup perubahan perilaku, apa yang dilakukan oleh klien dan bagaimana kemampuan klien sebelum mencapai tujuan manifestasi terhadap respon manusia : KAPP (Kognitif, Afektif, Psikomotor, dan Perubahan fungsi tubuh). Ciri-ciri Kriteria Keberhasilan adalah berhubungan dengan tujuan perencanaan keperawatan, bersifat khusus dan konkrit, hasilnya dapat dilihat, didengar, diraba dan diukur oleh orang lain dan dinyatakan dengan istilah yang positif.

Tujuannya setelah dilakukan tindakan keperawatan selama tujuh hari, klien mampu merawat kebersihan diri sendiri tanpa bantuan perawat. Kriteria nya adalah klien dapat mandi sendiri minimal 1x sehari, klien dapat mengganti pakaian sendiri minimal 1x sehari, mampu berdandan dengan rapi sesuai dengan waktu dan tepat. Formulasi Rumusan Tujuan 
Keperawatan adalah subjek (klien), perilaku klien yang dapat diamati oleh orang lain, predikat (kondisi) sertaa kriteria keberhasilan.

Petunjuk Umum dalam Menulis Tujuan adalah tulislah tujuan dalam istilah yang dapat diukur. Hindari kata-kata : baik, normal, cukup dan perbaikan, tulislah tujuan dalam istilah 'yang dapat dicapai oleh klien`, bukan tindakan keperawatan, tulis tujuan sesingkat mungkin, buat tujuan yang spesifik, setiap tujuan berdasarkan dari satu diagnosis keperawatan,rencanakan batas waktu untuk pencapaian setiap tujuan. Tulis tanggal tujuan dan tanggal evaluasi.

Tahap perencanaan adalah suatu proses penyusunan sebagai intervensi keperawatan yang dibutuhkan dalam mencegah, mengurangi dan menurunkan angka masalah masalah yang ada pada klien atau pasien.Perencanaan ini merupakan langkah ketiga dalam membuat perencaan keperawatan. Dalam hal ini perawat membutuhkan pengetahuan serta keterampilan diantaranya pengetahuan tentang kekuatan dan kelemahan klien, nilai dan kepercayaan klien, batasan praktek keperawatan, peran dari tenaga kesehatan lainnya ,kemampuan dalam memecahkan masalah, mengambil keputusan, menulis tujuan serta memilih dan membuat strategi keperawatan yang aman dalam memenuhi tujuan, menulis instruksi keperawatan serta kemampuan dalam melaksanakan kerjasama dengan tingkat kesehatan lain

Motivasi yang baik yang di miliki perawat yaitu dapat melakukan tugas dengan cakap tanggap dan terlihat bersemangat. Hal ini terlihat dari pasien puas dengan pelayanan serta kinerja yang di berikan perawat saat memberikan asuhan keperawatan. Dalam asuhan keperawatan di butuhkan keterampilan dan kemampuan untuk mengatasi permasalahan yang timbul serta mampu malaksanakan tindakan keperawatan sesuai SOP yang ada. Menurut Sumijatun permasalahan pelayanan keperawatan di negara Indonesia adalah banyaknya perawat yang belum melakukan asuhan keperawatan sesuai dengan standar. Asuhan keperawatan adalah kerangka kerja dan struktur organisasi yang kreatif untuk memberikan pelayanan keperawatan, namun asuhan keperawatan juga cukup fleksibel untuk digunakan disemua lingkup keperawatan.

Tujuan dari rencana perawatan adalah memberikan tindakan perawatan berdasarkan respon klien terhadap masalah kesehatannya,dan mencegah masalah baru yang akan timbul. Perencanaan dan tindakan keperawatan adalah tahap dalam proses keperwatan berdasarkan masalah aktual dari klien. Tujuan konsep dasar perencanaan adalah sebagai kerangka kerja dalam implementasi keperawatan,inti dokumentasi keperawatan yang berorientasi pada masalah, sebagai referensi dalam melkukan modifikasi rencana keperawatan,sarana 
komunikasi tim keperawatan dalam pendelegasian tugas/instruksi keperawatan,Sebagai landasan ilmiahyang logis dan sistimatis dalam mengerjakan asuhan keperawatan kepada pasien dan agar semua rencan tindakan dapat dipilih disesuaikan kondisi klien sehingga efektif.

Dalam perencanaan keperawatan, perawat menetapkannya berdasarkan hasil pengumpulan data dan rumusan diagnosa keperawatan yang merupakan petunjuk dalam membuat tujuan dan asuhan keperawatan untuk mencegah, menurunkan, atau mengeliminasi masalah kesehatan klien. Langkah-langkah dalam membuat perencanaan keperawatan meliputi: penetapan prioritas, penetapan tujuan dan kriteria hasil yang diharapkan, menentukan intervensi keperawatan yang tepat dan pengembangan rencana asuhan keperawatan. Setelah diagnosa keperawatan dirumuskan secara spesifik, perawat menggunakan kemampuan berfikir kritis untuk segera menetapkan prioritas diagnosa keperawatan dan intervensi yang penting sesuai dengan kebutuhan klien.

Dalam perencanaan keperawatan, perawat menetapkannya berdasarkan hasil pengumpulan data dan rumusan diagnosa keperawatan yang merupakan petunjuk dalam membuat tujuan dan asuhan keperawatan untuk mencegah, menurunkan, atau mengeliminasi masalah kesehatan klien. Langkah-langkah dalam membuat perencanaan keperawatan meliputi: penetapan prioritas, penetapan tujuan dan kriteria hasil yang diharapkan, menentukan intervensi keperawatan yang tepat dan pengembangan rencana asuhan keperawatan. Setelah diagnosa keperawatan dirumuskan secara spesifik, perawat menggunakan kemampuan berfikir kritis untuk segera menetapkan prioritas diagnosa keperawatan dan intervensi yang penting sesuai dengan kebutuhan klien. Penetapan prioritas bertujuan untuk mengidentifikasi urutan intervensi keperawatan yang sesuai dengan berbagai masalah klien. Penetapan prioritas dilakukan karena tidak semua masalah dapat diatasi dalam waktu yang bersamaan. Salah satu metode dalam menetapkan prioritas dengan mempergunakan hirarki kebutuhan menurut Maslow. Prioritas dapat diklasifikasi menjadi tiga tingkatan, antara lain high priority, intermediate priority, dan low priority. Dalam menetapkan prioritas perawat juga harus memperhatikan nilai dan kepercayaan klien terhadap kesehatan, prioritas klien, sumber yang tersedia untuk klien dan perawat, pentingnya masalah kesehatan yang dihadapi, dan rencana pengobatan medis. Diagnosa keperawatan klien dan penetapan prioritas membantu dalam menentukan tujuan keperawatan

\section{Penutup}

\section{Kesimpulan}


Konsep dasar Perencanaan keperawatan dalam asuhan keperawatan yang dipersiapkan oleh perawat harus berhubungan dengan kondisi pasien berdasarkan pengkajian dan diagnose keperawatan. Perencanaan keperawatan menjadi dasar perawat dalam mengimplementasikan tindakan yang akan dilakukan. Beberapa hal yang perlu diperhatikan dalam perenacanan keperawatan seperti menentukan prioritas masalah, menentukan tujuan dan kriteria hasil yang diharapkan, merumuskan rencana tindakan keperawatan dan rasional rencana tindakan keperawatan. Perencanaan keperawatan merupakan bagian dari proses keperawatan yang bermanfaat dalam pelayanan dan asuhan yang akan diberikan perawat kepada pasien.

\section{Saran}

Pada dasarnya setiap perawat harus mampu meningkatkan mutu dan kualitas pelayanan keperawatan secara optimal dengan tetap menerapkan konsep dasar perencanaan keperawatan dalam melaksanakan asuhan keperawatan. Agar pelayanan yang diberikan kepada pasien maksimal dan pasien merasa nyaman atas tindakan yang diberikan oleh perawat.

\section{Daftar Pustaka}

Aini, D. N. (2018). Hubungan Kualitas Pelayanan Keperawatan dengan Tingkat Kepuasan Pasien Rawat Inap di RSUD DR. H. SOEWONDO KENDAL. Jurnal Ners Widya Husada Semarang, 2 .

Butar-Butar, J., \& Simamora, R. H. (2016). Hubungan Mutu Pelayanan Keperawatan dengan Tingkat Kepuasan Pasien Rawat Inap di RSUD Pandan Kabupaten Tapanuli Tengah. Jurnal Ners Indonesia, 6(1), 50-63.

Efendi,N.F.(2015). Pendidikan dalam keperawatan. Surabaya: Salemba Medika

Hafaz, I. (2019, September 28). Memaksimalkan proses berpikir kritis oleh perawat dalam melakukan pelayanan di bidang kesehatan. Osf.io.

Mandagi, F. M., Umboh, J. M. L., \&Rattu, J. A. M. (2015). Analisis Faktor - Faktor Yang Berhubungan Dengan Kinerja Perawat Dalam Menerapkan Asuhan Keperawatan Di Rumah SakitUmum Bethesda Gmim. Jurnal E-Biomedik, 3(3). https://doi.org/10.35790/ebm.3.3.2015.10479 
Ramadani,T.(2019).Pengetahuan Dan Sikap Perawat terhadap Perencanaan Asuhan Keperawatan. https://doi.org/10.31227/osf.io/rfwy5

Rof'i Muhamad., Tutik Sri Haryati., Pujasari Hening. (2012). Perjanjian dan Konsensus dalam Pelaksanaan Perencanaan Pulang Pada Perawat Rumah Sakit. Jurnal Keperawatan Indonesia. 15 (3). 2017-214.

Saputra, H. (2014). Hubungan Penerapan Asuhan Keperawatan dengan Pemenuhan Kebutuhan Spiritual Pasien di Ruang Rawat Inap Kelas III RS PKU Muhammadiyah Yogyakarta. 1-19.

Simamora, R. H. (2005). Hubungan Persepsi Perawat Pelaksana Terhadap Penerapan Fungsi Pengorganisasian Yang Dilakukan Oleh Kepala Ruangan Dengan Kinerjanya Diruang Rawat Inap RSUD Koja Jakarta Utara (Doctoral dissertation, Tesis FIK UI, Tidak dipublikasikan).

Sugiyono, P. D. (2016). Journal of Chemical Information and Modeling, 53(9), 1689-1699. https://doi.org/10.1017/CBO9781107415324.004

Sulistyowati, D., \& Handayani, F. (2012). Peran Perawat dalam Pelaksanaan Personal Hygiene menurut Persepsi Imobilisasi Fisik. Jurnal Nursing Studies, Vol. 1, no. 1

Wirdah, H., \& Yusuf, M. (2016). Penerapan Asuhan Keperawatan oleh PerawatPelaksana di Rumah Sakit Banda Aceh. PSIK Unsyiah, 1(1), 1-6. 